\title{
Early Ordovician black corals from China
}

\author{
ANDRZEJ BALIŃSKI \& YUANLIN SUN
}

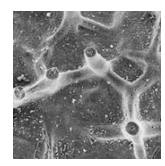

\begin{abstract}
Despite the importance of black corals in modern coral faunas and marine ecosystems, they were unknown in the fossil record until the recent discovery of abundant phosphatised remains in the Lower Ordovician Fenxiang Formation in the Three Gorges area (Hubei Province) of South China. The poor fossil record of black corals could be explained by their unmineralized skeleton composed mainly of laminar chitin complexed with the protein antipatharin. Here, we describe three species of black corals from the Fenxiang Formation: Sinopathes reptans Baliński, Sun \& Dzik, 2012, Sinopathes sp., and Sterictopathes radicatus gen. et sp. nov. A new family Sinopathidae is proposed for the Early Ordovician genera Sinopathes and Sterictopathes. Coralla of both these genera consist of an encrusting basal plate and ascending branches, both covered with long spines. However, whereas in Sinopathes the surface of the skeleton is smooth and all spines are longitudinally striated, in Sterictopathes the spines are smooth, but basally buttressed by radiating, plate-like ridges forming anastomosing network on basal plate and branches. Biotic interactions among studied black corals and other organisms in the form of bioimmuration, encrustation and probable parasite/predatory markings are also described. Key words: China, Ordovician, Fenxiang Formation, black corals, Sinopathes, Sterictopathes gen. nov., Sinopathidae fam. nov.
\end{abstract}

BALIŃSKI, A. \& SUN, Y. 2017. Early Ordovician black corals from China. Bulletin of Geosciences 92(1), 1-12 (8 figures). Czech Geological Survey, Prague. ISSN 1214-1119. Manuscript received September 15, 2016; accepted in revised form November 18, 2016; published online February 17, 2017; issued March 31, 2017.

Andrzej Baliński (corresponding author), Institute of Paleobiology, Polish Academy of Sciences, Twarda 51/55, PL-00-818 Warszawa, Poland; balinski@twarda.pan.pl・ Yuanlin Sun, Key Laboratory of Orogenic Belts and Crustal Evolution, School of Earth and Space Sciences, Peking University, Beijing 100871, China; ysun@pku.edu.cn

Present-day antipatharians, also known as black corals, are exclusively colonial marine suspension feeders represented by over 235 species grouped into 43 genera (France $e t$ al. 2007, Lapian et al. 2007, Wagner et al. 2012, Wagner \& Opresko 2015). A majority of antipatharian species inhabit tropical and subtropical regions in deeper-water to abyssal depth environments, but they can also be found in subtidal and polar settings (Wagner et al. 2012, Brugler et al. 2013). The skeleton of black corals (corallum) is composed of laminar chitin complexed with the protein antipatharin (Williams et al. 2006). The skeletal elements built of a chitin-protein complex do not preserve in older rocks unless transformed to aliphatic compounds and phosphatised (Gupta \& Briggs 2011). This could have been the case with the phosphatised early Ordovician material described here. It is difficult to explain why these corals have not been found in rocks of other age and localities. However, the upper Cambrian Palaeobotryllus Müller, 1977 originally interpreted as ascidian (Müller 1977) may, in fact, represent antipatharians.

Antipatharian corallum is completely covered with an epithelial tissue that secretes it basally in concentric layers. Colonies are attached to the substrate through a basal plate or a hook-like holdfast. Generally, the vertical growth rates of antipatharians do not exceed a few centimeters per year, while the radial growth rates can be as low as 4-35 $\mu$ m per year (Roark et al. 2009). The life-span of an antipatharian colonies can reach tens to thousands of years. The longest-lived Leiopathes sp. colonies were estimated to been growing for about 4,265 years (Roark et al. 2009).

Despite the abundance of black corals in modern deeper water coral faunas and their importance to recent marine ecosystems, they were almost completely unknown in the fossil record prior to the discovery of abundant remains interpreted as representing black corals in the Lower Ordovician Fenxiang Formation in southern China (Baliński et al. 2012). Otherwise, there was only a brief remark on the presence of Leiopathes in the Miocene of Italy by Wells \& Hill (1956), but without any description. Thus, the finding of the rich fossil assemblage of phosphatised black corals in the Ordovician is of importance for understanding the timing of anthozoan phylogeny (Baliński et al. 2012). Based on mitochondrial DNA data Brugler \& France (2007) concluded that the Antipatharia are the sister taxon to the Actiniaria (see also Rodriguez et al. 2014). Recent molecular analyses based on mitochondrial and nuclear 

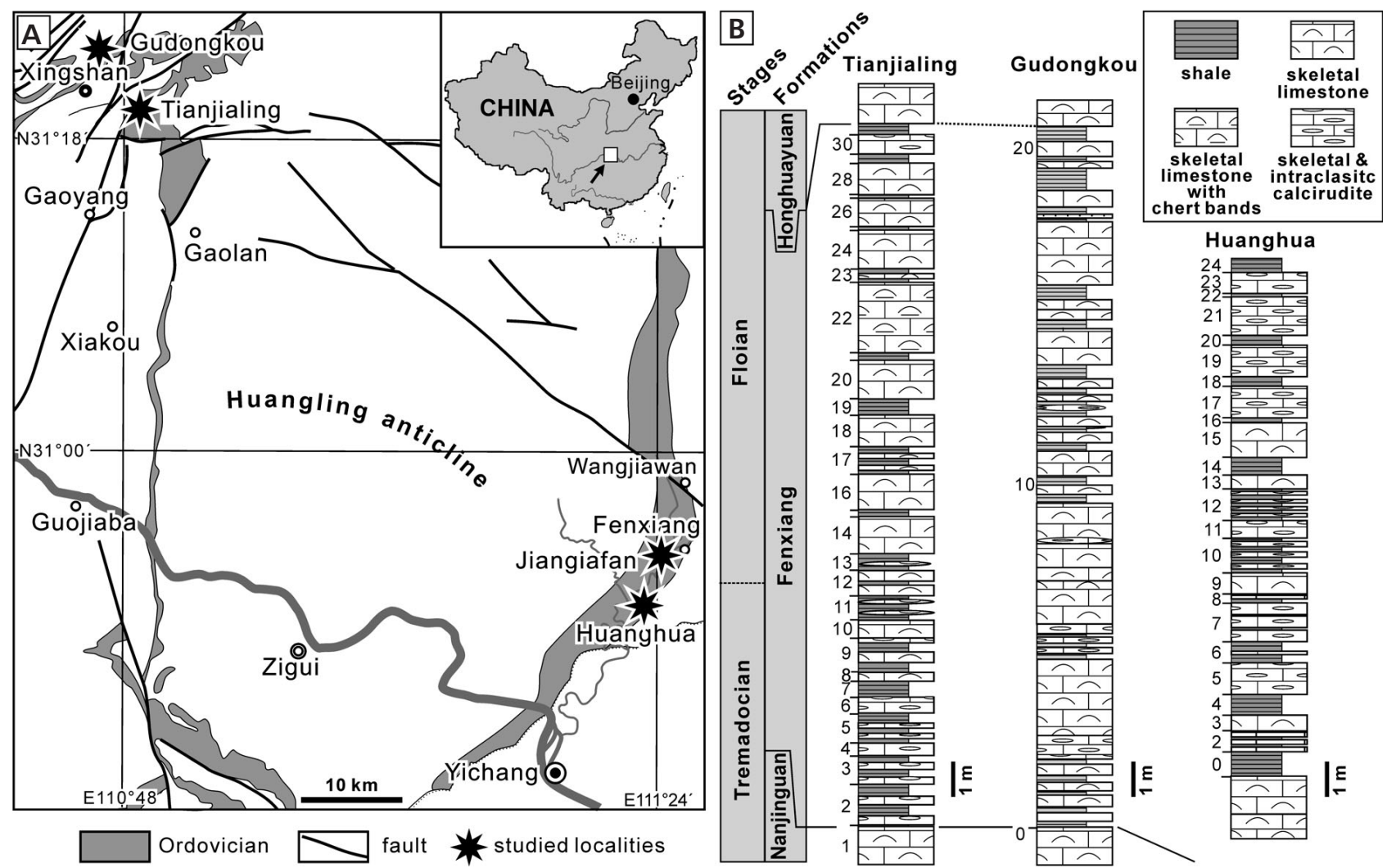

Figure 1. Geographic location and stratigraphy of studied sites (marked by stars) in the Three Gorges area of Hubei Province, southern China (GPS coordinates: Tianjialing, $31^{\circ} 19^{\prime} 11.6^{\prime \prime} \mathrm{N}, 110^{\circ} 48^{\prime} 30.5^{\prime \prime} \mathrm{E}$; Gudongkou, $31^{\circ} 21^{\prime} 58.1^{\prime \prime} \mathrm{N}, 110^{\circ} 45^{\prime} 11.9^{\prime \prime} \mathrm{E}$; Huanghua, 30 $51^{\prime} 36.94^{\prime \prime} \mathrm{N}, 111^{\circ} 21^{\prime} 49.64^{\prime \prime} \mathrm{E}$; Jiangiafan, $\left.30^{\circ} 53^{\prime} 37.44^{\prime \prime} \mathrm{N}, 111^{\circ} 23^{\prime} 53.31^{\prime \prime} \mathrm{E}\right)$. $・ \mathrm{~A}$ - simplified locality map. • B - rock columns of the Fenxiang Formation at Tianjialing, Gudongkou and Huanghua showing distribution of black coral species.

markers have shown that the first split of lineages within the Scleractinia took place deep in the Paleozoic, i.e., about $425 \mathrm{Ma}$ ago (Stolarski et al. 2011). Thus, the emergence of the antipatharian lineage must have taken place much earlier. This agrees well with the present record of phosphatised remnants interpreted here as representatives of antipatharians. Moreover, the Early Ordovician forms reveal a highly derived skeleton indicating an even more ancient origin of the group (Baliński et al. 2012).

\section{Material and geological setting}

The present material was collected from the Fenxiang (transcribed also as Fenhsiang) Formation of the Three Gorges area (Yichang area) in Hubei Province of South China. The main collecting sites from which the studied material comes include the Tianjialing and Gudongkou sections in Xingshan County, situated on the western limb of the Huangling Anticline, as well as Huanghua and Jiangjiafan (= Chenjiahe) quarries near Yichang, located on the eastern limb of the anticline (Fig. 1). The Fenxiang Formation consists mainly of dark to medium grey skeletal and peloidal limestone intercalated with greenish grey shale and occasionally with reef limestone representing the oldest such build-ups constructed by bryozoans, lithistid sponges, pelmatozoans, stromatoporoids, and calcimicrobes (Adachi et al. 2012, 2013). The formation is about $20 \mathrm{~m}$ thick in the west side of the anticline and can reach over $50 \mathrm{~m}$ in the east side. Although until recently the Fenxiang Formation was regarded as Tremadocian in age (e.g., Zhan \& Jin 2007, Wu et al. 2010, Adachi et al. 2011), latest data on conodont fauna from the formation indicate that at least its upper part represents early Floian (Arenig in British terms; Serratognathus diversus Zone; about $477 \mathrm{Ma}$ ) (Baliński et al. 2012).

Lithology and the faunal content of the Fenxiang Formation imply a rhythmic change of the sedimentary regime from low-energy, deeper-water basin to energetic, shallow-water carbonate platform. Some of the fossil remnants recovered from shale suggest that they are allochthonous, derived from shallow-water, peri-reefal origin and subsequently transported to open-marine, deeper-water settings with final deposition on the muddy bottom in sediments rich in organic matter (Baliński \& Sun 2015, Dzik et al. 2016). This taphonomic setting made possible pyritization 

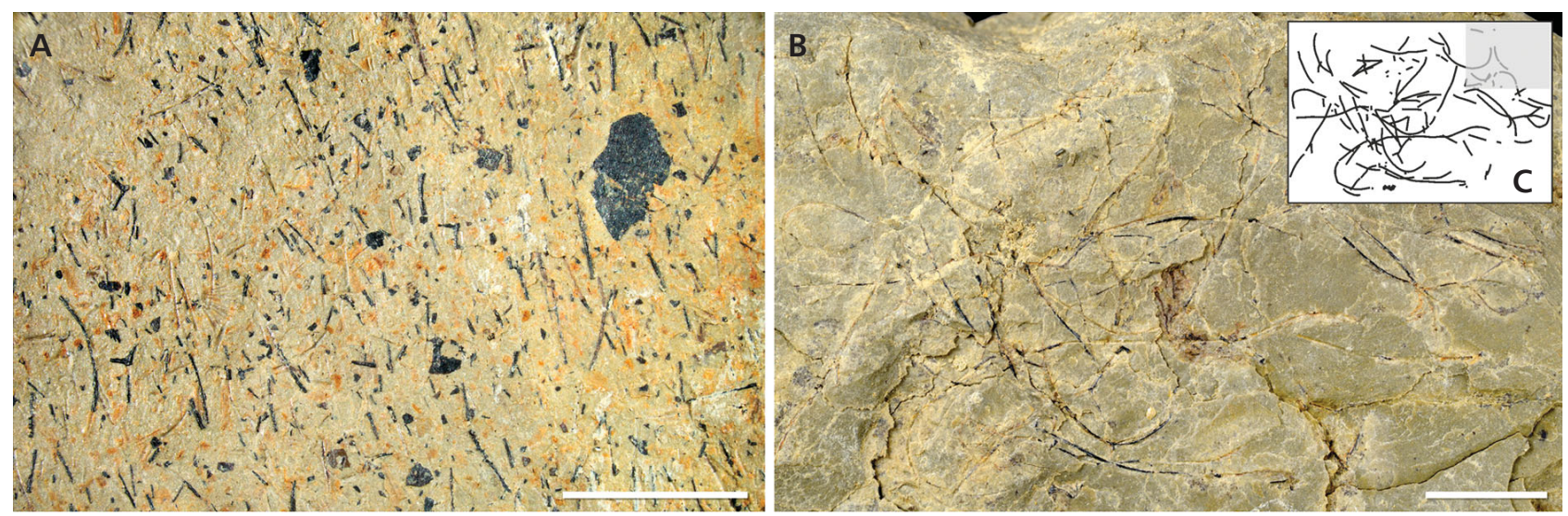

Figure 2. Typical occurrences of black corals in shale of the Lower Ordovician Fenxiang Formation at the Tianjialing section. • A - surface with detritus of black corals and lingulide shells; ZPAL H. 27/32a. • B - several large fragments of coralla showing flexibility of curved branches; ZPAL H. 27/32b. - $\mathrm{C}$ - explanatory drawing of B showing distribution of skeletal fragments. Scale bars $5 \mathrm{~mm}$.

of soft tissue of several invertebrates including lingulate brachiopods (Baliński \& Sun 2013), colonial hydrozoans (Baliński et al. 2014) and problematic clonal organisms of possible hemichordate affinities (Dzik et al. 2016). Infaunal activity of microscopic nematodes is also recorded as pyritized sinusoidal burrows (Baliński et al. 2013). Secondarily phosphatised and usually highly fragmented remains of antipatharian coralla occur abundantly in the Fenxiang Formation (Fig. 2), both in shale and in residues of samples taken from limy intercalations and processed in formic or acetic acids.

\section{Comparisons and discussion}

As has been shown earlier (Baliński et al. 2012), the ramose, multilayered and spinose skeleton of Sinopathes reptans is consistent with the morphologic characteristics of antipatharian corals. No other fossil or recent organisms match these basic aspects of the skeletal morphology of the early Ordovician species. Despite of this, Brugler et al. (2013, p. 313) questioned the antipatharian relationship of Sinopathes reptans because: “...antipatharian spines do not form distinct, continuous longitudinal ridges, are not tubular in structure, and do not have a central canal". They hypothesized that these fossils are rather representative of a cnidarian closely related to the hydrozoan Hydractinia (Brugler et al. 2013). In fact, the spines of S. reptans never form even indistinct longitudinal ridges, as was abundantly illustrated by Baliński et al. (2012; also this paper Fig. 3). This makes the first objection of Brugler et al. (2013) invalid. Moreover, numerous cross-sections of spines in S. reptans (Baliński et al. 2012, figs 3k, 4g, i; this paper Fig. 3M, $\mathrm{N})$ clearly reveal that these spines are multilayered and solid, not tubular. An exceptionally observed small central lumen in some broken spines is a preservational artifact.
The present material of skeletal elements that are frequently incompletely phosphatised in their inner layers was chemically extracted from limestone samples. The similarity of $S$. reptans to extant black corals is apparent. On the contrary, the similarity of Sinopathes to the extant hydroid Hydractinia, which develops conical spines on the basal mat, is not greater than between Hydractinia and other antipatharian corals. Sinopathes, like other black corals, forms upright, branched colonies whereas mat-like or stoloniferous growth forms are typical for Hydractinia (e.g., Cartwright 2003). No fossil or recent taxa, other than the antipatharian corals, fits the morphology of the Chinese species (Baliński et al. 2012, p. 650).

The main difference between Sinopathes and recent antipatharians that deserves comment is the distribution of spines. In $S$. reptans the spines are distributed irregularly and vary in size and shape whereas in most extant antipatharians they are rather uniform and arranged most often in longitudinal rows. This difference refers to organisms separated by almost a half billion year time gap. In fact, an irregular pattern of distribution of spines is quite frequent in many genera and species of the present-day antipatharians. Even if the spines are usually arranged in more or less regular longitudinal rows on branches and pinnules, the spines frequently show an irregular pattern on the stem (e.g., Opresko 2001, pp. 356, 362; Balinski et al. 2012, fig. 3f; here Fig. 3P). Occasionally, spines are distributed randomly even on the major branches (e.g., Pasternak 1977, pp. 157, 160; Grange 1988, p. 56; Opresko 2004, pp. 221, 224; 2006, p. 111; Bo et al. 2012, p. 70; Wagner \& Opresko 2015, pp. 278, 280, 284). In some black corals with two size classes of spines, smaller spines are distributed irregularly between larger ones, with no apparent pattern, as in, e.g., Cirripathes secchini Echeverría, 2002 (Echeverría 2002, p. 1068). It seems likely that the irregular arrangement of spines in the Ordovician forms is 
a plesiomorphic trait and that a subsequent evolutionary trend was towards regularity (Baliński et al. 2012).

Another Ordovician species interpreted as representing a black coral shows advanced aspects of morphology that are not necessarily known in extant forms. It should be noted that none of the present-day antipatharians possesses a network of ridges supporting the spine bases similar to those found in the early Ordovician Sterictopathes radicatus gen. et sp. nov. This difference does not seem important because rudimentary ridges may be developed in recent antipatharians, although much less frequently. For example, in Dendrobathypathes boutillieri Opresko, 2005 spines are laterally compressed and have their bases prolonged into longitudinal ridges connecting the adjacent spines (Brugler et al. 2013, fig. 8a). Similar longitudinal ridges occur in Antipathella subpinnata (Ellis \& Solander, 1786) (Opresko 2001, fig. 16a) and in Aphanipathes verticillata mauiensis Opresko, Wagner, Montgomery \& Brugler, 2012 (Opresko et al. 2012, fig. 8d). Laterally compressed spines on the tips of pinnules, with their bases forming long sub-longitudinal ridges, have been illustrated in Parantipathes euantha (Pasternak, 1958) by Molodtsova \& Pasternak (2005, fig. 2a) and in Abyssopathes lyriformis Opresko, 2002 by Opresko (2002, fig. 7b). Especially impressive are longitudinal ridges shown by Wagner \& Opresko (2015, fig. 4j) in Leiopathes annosa Wagner \& Opresko, 2015. The occurrence in the early Ordovician of such forms as Sterictopathes radicatus with a strong network of ridges on the surface of the corallum, as well as Sinopathes reptans, which has a smooth spinose surface of its colony, may express high morphological differentiation of the early antipatharians. This seems to be a reflection of different ways to solve the problem of mechanical strength of the skeleton.

\section{Systematic palaeontology}

Phylum Cnidaria Hatschek, 1888

Class Anthozoa Ehrenberg, 1834
Subclass Hexacorallia Haeckel, 1966

Order Antipatharia Milne Edwards \& Haime, 1857

Family Sinopathidae fam. nov.

Type genus. - Sinopathes Baliński, Sun \& Dzik, 2012; Early Ordovician, Fenxiang Formation, Hubei province, China.

Other genera included. - Sterictopathes gen. nov., stratigraphic and geographic range as for the type genus. Enigmatic upper Cambrian fossil known as Palaeobotryllus Müller, 1977 may be related to the family.

Diagnosis. - Colony consists of encrusting basal plate and upright, branched stalk, both covered by irregularly arranged spines. Branches smooth or with plate-like radiating ridges supporting spines. Spines vary in size and shape, usually 160-230 $\mu \mathrm{m}$ in 1 ength, the longest reach $600 \mu \mathrm{m}$; surface smooth or densely longitudinally striated.

Stratigraphic range. - Tremadocian to Floian, Early Ordovician.

\section{Genus Sinopathes Baliński, Sun \& Dzik, 2012}

Type species. - Sinopathes reptans Baliński, Sun \& Dzik, 2012; vicinity of Tianjialing village, Yichang area, Hubei Province, China; Fenxiang Formation, early Arenigian.

\section{Sinopathes reptans Baliński, Sun \& Dzik, 2012}

Figures 2-4

Material. - About a thousand specimens from the residue of acid-processed limestone samples, more than 200 have been mounted on SEM stubs for detailed investigation.

Description. - The skeleton consists of the encrusting basal plate (holdfast) and upright, branched stalk; both are covered by spines.

Figure 3. Skeletal elements of extant and Early Ordovician antipatharians. - A, P, T - lateral branch, main branch and spine of extant Antipathes subpinnata (Ellis \& Solander, 1786) from the Strait of Messina (Tyrrhenian Sea); note irregular distribution of spines in P and lamellar structure of a broken spine in T; ZPAL H. 27/16-1 (A), ZPAL H. 27/10-2 (P, T). B-O, Q-S, U-Y - Sinopathes reptans Baliński, Sun \& Dzik, 2012 from the Lower Ordovician Fenxiang Formation of Hubei Province, China. • B-E, H-L - lateral braches; ZPAL H. 27/2-18 (B), ZPAL H. 27/30-28 (C), D H. 27/7-16 (D), E ZPAL H. 27/30-14, ZPAL H. 27/28-21 (H, I), ZPAL H. 27/5-17 (J; illustrated by Balinski et al. 2012, fig. 2g), ZPAL H. 27/18-26 (K), ZPAL H. 27/18-3 (L). - F, G - fragmentarily preserved spinose basal plates with erect spinose braches; ZPAL H. 27/8-1 (F; new photograph of the specimen illustrated by Balinski et al. 2012, fig. 2k), ZPAL H. 27/27-15 (G).・M, N - fragment of lateral branch with spines showing lamellar structure in transverse fracture; ZPAL H. 27/8-7. • O, Q-S, V, X - fragments of spinose basal plates; ZPAL H. 27/31-26 (O), ZPAL H. 27/23-21 (Q; illustrated by Balinski \& Sun 2015, fig. 31), ZPAL H. 27/6-7 (R), ZPAL H. 27/23-14 (S), ZPAL H. 27/2-4 (V; new photograph of the specimen illustrated by Balinski et al. 2012, fig. 4m), ZPAL H. 27/24-31 (X). • U, W - detailed morphology of spines; note external longitudinal ridges visible in broken spine also on deeper growth layers in U; ZPAL H. 27/8-13 (U), ZPAL H. 27/6-1 (W). • Y - enlargement of well-preserved spine showing surface sculpture and blunt tip; ZPAL H. $27 / 24-37$. Samples: Tianjialing T5 (Q, S), Tianjialing T13 (B-D, F, G, J-N, R, U-Y), Huanghua H18 (E, H, I), Huanghua HB5 (O). Scale bars 500 um (A-H, J-L), $100 \mu \mathrm{m}(\mathrm{I}, \mathrm{M}, \mathrm{P}-\mathrm{S}, \mathrm{V}-\mathrm{X})$ and $50 \mu \mathrm{m}(\mathrm{T}, \mathrm{U}, \mathrm{Y})$. 


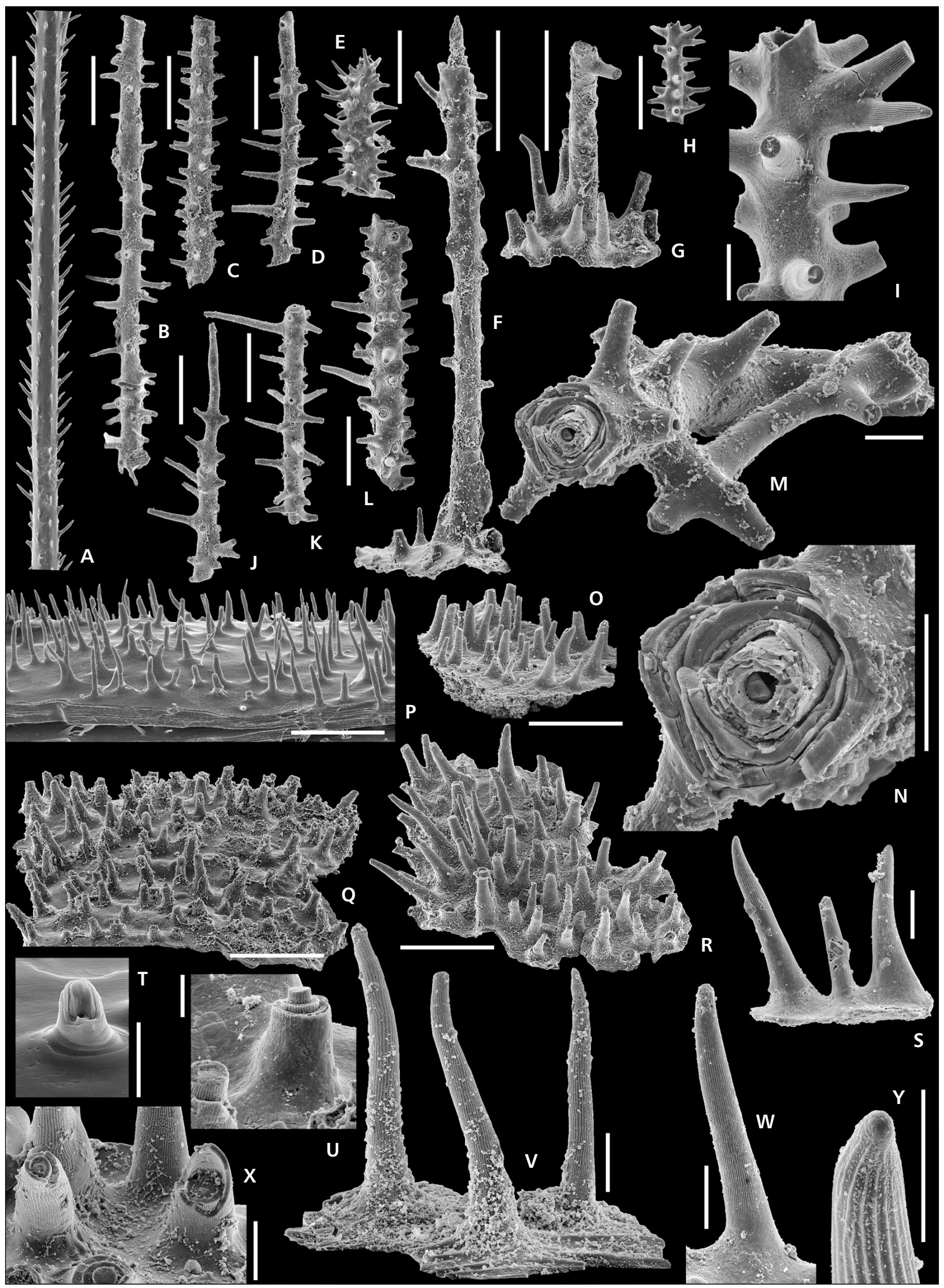



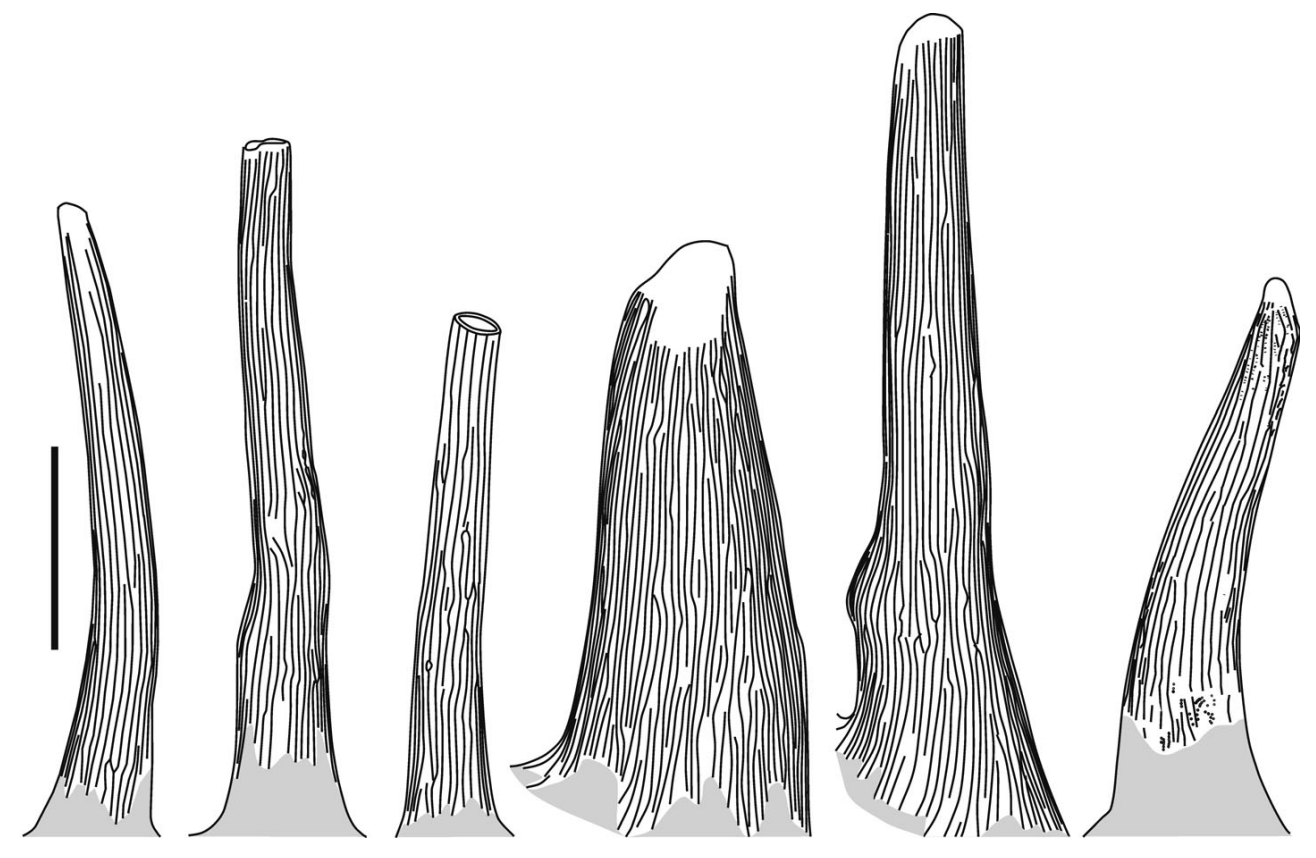

Figure 4. Diagrammatic presentation of variability of longitudinal sculpture on spines in Sinopathes reptans Baliński, Sun \& Dzik, 2012 from the Lower Ordovician Fenxiang Formation of Hubei Province, China.
Basal unit. The basal unit is multilayered in structure, but thin and delicate, prone to damage during preparation, unless it is preserved together with a substrate to which the coral is fixed. The thickness of the basal unit varies widely, but most often attains 10-20 $\mu \mathrm{m}$ (total range 5-56 $\mu \mathrm{m}$ ). Usually its upper surface, apart from spines, is smooth or weakly wrinkled whereas its lower surface replicates the surface of a substrate. The upper surface of the holdfast is covered by irregularly distributed spines. The density of spines varies considerably within a range of 25-53 spines per $1 \mathrm{~mm}^{2}$ (Fig. 3O, Q-S, V).

Stem and branches. The stem grows more or less perpendicular to the basal unit, is multilayered, branched and tubular with rounded cross-section and central canal (Fig. 3F, G). Branches are long, straight to gently arched, irregularly distributed on the stem. Specimens preserved on the shale surface show that the colony of $S$. reptans was characterized by long and flexible ramifications (Fig. 2B). The branches occasionally bifurcate at about a right angle or obliquely relative to the lower order branch. Some lateral branches may anastomose forming a rigid structure (Fig. 3M). Branches attain 40 to $360 \mu \mathrm{m}$ in diameter. In cross section they reveal multilayered structure and a wide central lumen which, however, may be markedly reduced in the thickened specimens (Fig. 3M, N). Branches are covered with irregularly distributed spines of the same type as those on the basal unit. Spine density varies greatly but generally diminishes distally; branches thinner than about $70 \mu \mathrm{m}$ are usually spineless (Fig. 3J).

Spines. They vary considerably in size and shape, but most often are slender, narrowly conical to acicular, straight to slightly bent or inclined and 330-600 $\mu \mathrm{m}$ in length. Exceptionally, the spines may bifurcate (Fig. 3I). The base of spines is wide, $40-140 \mu \mathrm{m}$ in diameter, conical with smooth surface. Distal end of spines is narrowing with bluntly rounded apex (Fig. 3Y) attaining 13-30 $\mu \mathrm{m}$ in diameter. Apart from basal region and apex, the spines are sculptured with faint, sharp, longitudinal, 1- $\mu \mathrm{m}$-wide ridges. These ridges or stripes are spaced every 3.0-4.5 $\mu \mathrm{m}$ and run more or less parallel to each other. They are usually simple, but occasionally may intercalate or bifurcate (Fig. 4). In cross-section the spines show a solid, multilayered structure, with successive laminae stacked one above the other (Fig. 3U, X) identically as in branches. Delaminated spines show characteristic external sculpture (longitudinal ridges) developed on preceding internal layers (Fig. 3U).

Remarks. - The difference between S. reptans and Sterictopathes radicatus gen. et sp. nov., described below, is discussed in the description of the latter. It is noteworthy that sculptured spines virtually identically to those in S. reptans were described by Müller (1977) in the upper Cambrian Palaeobotryllus. The latter was compared to present-day ascidians (Müller 1977, Lehnert et al. 1999), but recently a corallum-like appearance has been suggested (Baliński et al. 2012).

Occurrence. - The Fenxiang Formation; Tianjialing: beds T4, T5, T13, T17; Huanghua: beds HB5, HB18; Gudongkou: bed $111 \mathrm{~K}$; Jianjiafan: bed C(-3); a few poorly preserved specimens were found at the base of the Honghuayuan Formation at Gudongkou (sample 118A). 
Figure 5. Morphology of branches of Sinopathes sp. from the Lower Ordovician Fenxiang Formation of Hubei Province, China. - A, B - two fragmentary specimens in different growth stages showing partly broken spines; ZPAL H. 27/21-18 (A), ZPAL H. 27/27-8 (B). • C-E thick-walled branch in general, oblique and enlarged views; note a smooth acicular spine in E; PKUM 2014-22. Samples: Gudongkou G50 (A), Gudongkou 115E (C-E), Tianjialing T13 (B). Scale bars $200 \mu \mathrm{m}$ (A-D) and $50 \mu \mathrm{m}$ (E).

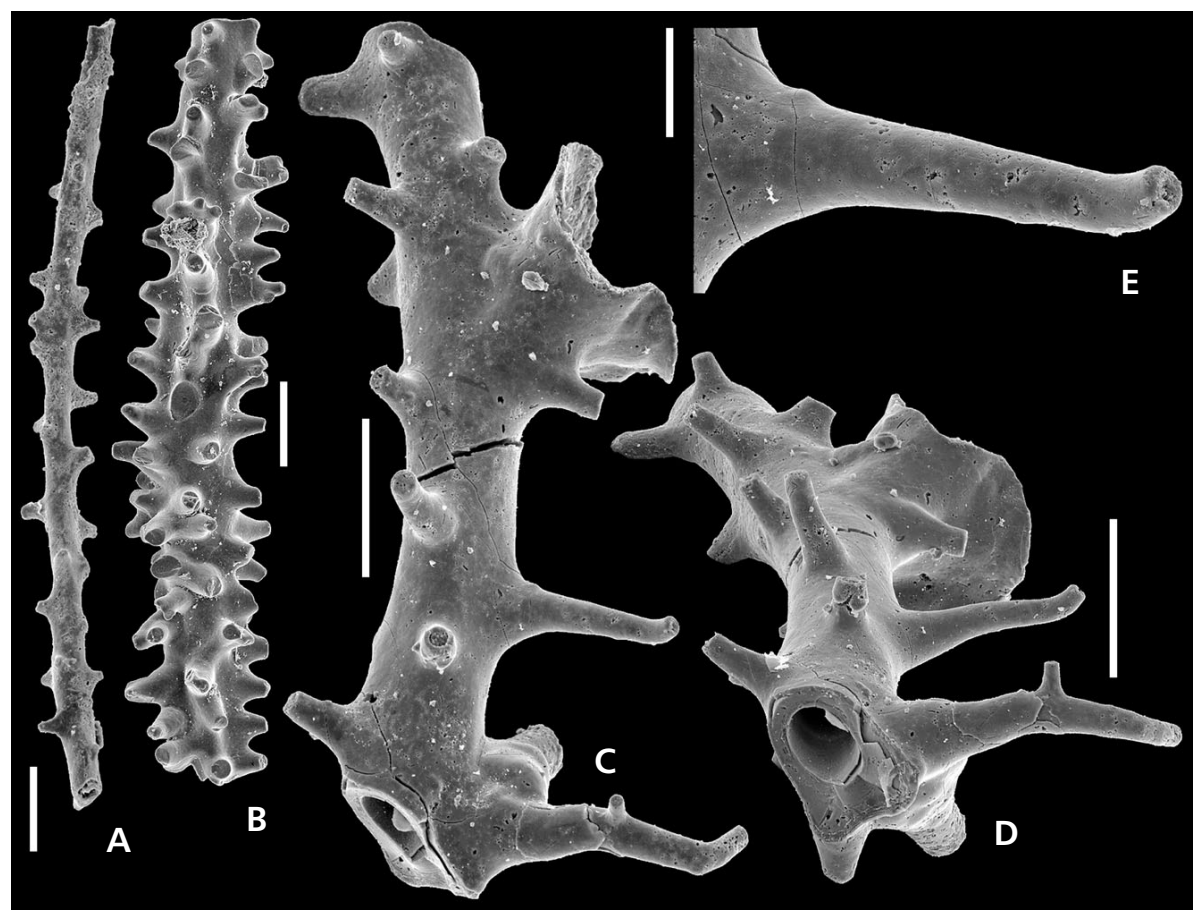

\section{Sinopathes sp.}

Figure 5

Material. - Twelve fragmentary branches.

Remarks. - This form resembles in many respects the type species of the genus. The only significant difference from $S$. reptans is a total absence of characteristic longitudinal ridges on spines in $S$. sp., which are invariably well developed in $S$. reptans. It seems that the smoothness of spines is not just a result of their worn surfaces and poor preservation, because smooth, non-sculptured deeper layers visible in broken spines which may be expected to be better preserved, are also smooth (in $S$. reptans the deeper layers of broken spines bear the same ornamentation as the exterior). The limited present material, however, justifies a description in open nomenclature.

Occurrence. - Fengxiang Formation at Tianjialing (bed T13), Huanghua (bed 20) and Gudongkou (samples G50 and $115 \mathrm{E}$ ). In addition, a few poorly preserved specimens were recovered from the Fengxiang Formation at Jianjiafan [bed $\mathrm{C}(-1)]$ and the Dawan Formation at Gudongkou (sample G70).

\section{Genus Sterictopathes gen. nov.}

Type species. - Sterictopathes radicatus gen. et sp. nov.; Huanghua quarry, Yichang area, Hubei Province, China; Fenxiang Formation, earliest Floian.
Etymology. - Greek steriktos, solidly supported - from ridges buttressing spines, and the commonly used suffix "pathes".

Diagnosis. - Antipatharian with extensive encrusting basal plate and erect branches, both with slender, acicular spines; spines with smooth surfaces, basally buttressed by radiating, strong, frequently plate-like ridges with tendency to form an anastomosing network.

Remarks. - The difference between Sterictopathes gen. nov. and Sinopathes is discussed in the description of Sterictopathes radicatus gen. et $\mathrm{sp}$. nov.

\section{Sterictopathes radicatus sp. nov.}

Figures 6, 7

Holotype. - ZPAL H. 27/31-17, incomplete basal plate of the colony.

Type locality. - Huanghua quarry, the Yichang area, Hubei Province, China.

Type horizon. - Earliest Floian (Arenig) Fenxiang Formation, bed HB5.

Etymology. - From Latin root, radix - after radial ridges buttressing spines, which are reminiscent of platelike supporting roots of the trees, mainly found in tropical rain forests. 


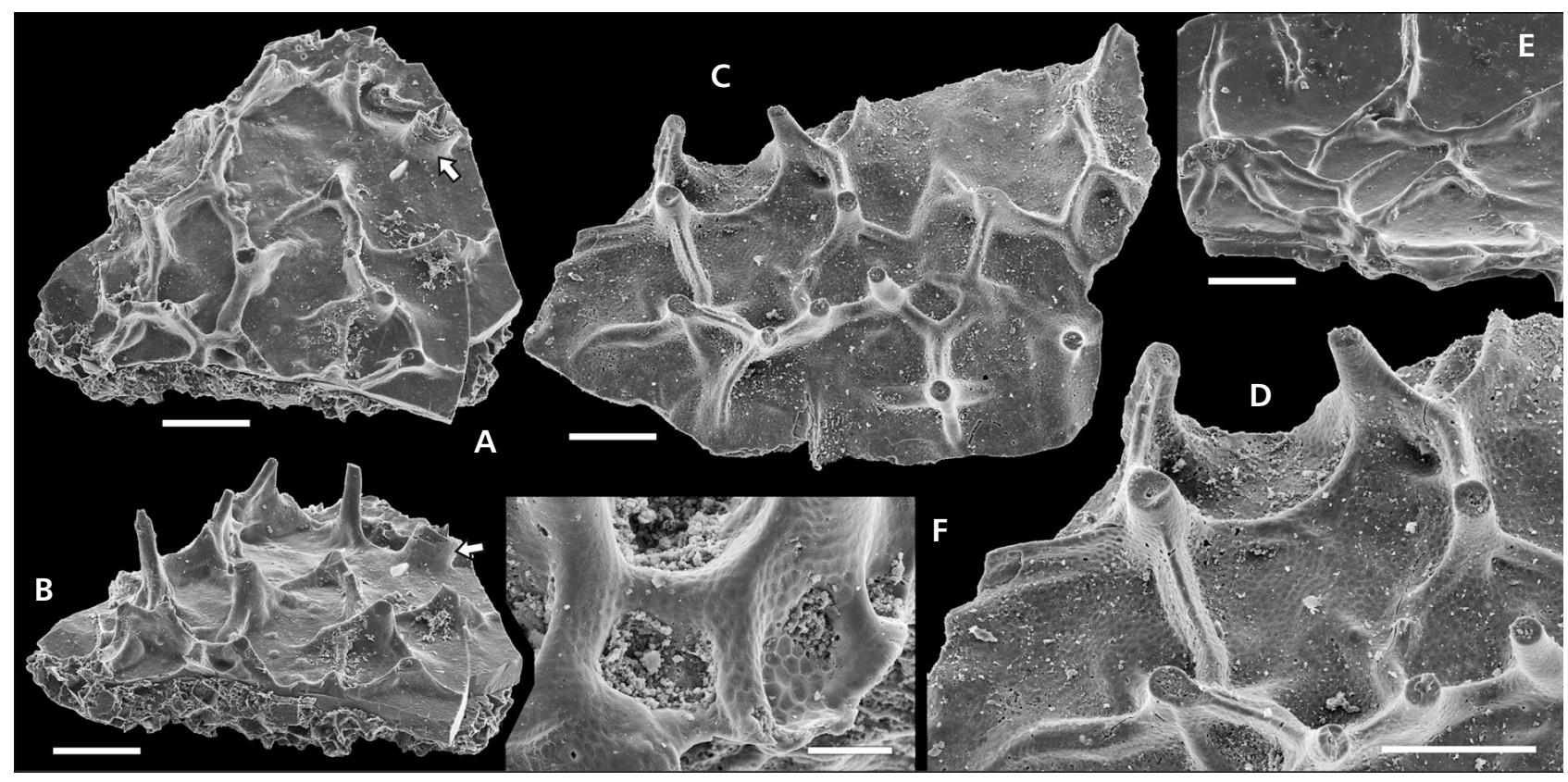

Figure 6. Morphology of basal plate in Sterictopathes radicatus gen. et sp. nov. from the Lower Ordovician Fenxiang Formation of Hubei Province, China. $\bullet$ A, B - incompletely preserved basal plate in normal and oblique views showing broken in various extent spines, radiating ridges and basal part of the broken main stem (arrowed); ZPAL H. 27/28-19. • C, D - holotype, broken basal plate showing external morphology in general and enlarged views; ZPAL H. 27/31-17. • E - basal plate encrusting internal surface of a broken Sphenothallus tube; ZPAL H. 27/28-2. • F - enlargement of external surface of a branch showing clearly visible imprints of epithelial cells; ZPAL H. 27/20-31. Samples: Huanghua HB8 (A, B), Huanghua HB5 (C, D), Huanghua HB7 (E), Tianjialing T5 (F). Scale bars $200 \mu \mathrm{m}(\mathrm{A}-\mathrm{E})$ and $50 \mu \mathrm{m}(\mathrm{F})$.

Diagnosis. - As for the genus.

Material. - About 130 specimens selected from the residua and investigated in SEM.

Description. - The present material consists mainly of broken branches and less frequently of basal part of colonies.

B a sal unit. The unit is multilayered in structure with a total thickness ranging from 12 to $58 \mu \mathrm{m}$. General shape of the unit strictly reflects the surface of the substratum that the colony encrusts. Thus, it may be more or less flat (Fig. 6A-D) or curved, as in the case of encrusting the tubes of Sphenothallus (Figs 6E, 8E-G). In the latter case the basal unit may be convex or concave depending on whether it encrusts the external (Fig. 8E, G) or internal (Figs 6E, 8F) surface of the tube. The upper surface of the basal unit is more or less smooth, sometimes weakly tuberculate, but always covered with spines and strong ridges, which extend radially from the spine bases (Fig. 6A-E). These ridges produce a strong anastomosing pattern spreading from nodes that are formed by spine bases. Most often there are three to four ridges radiating from each spine base. The ridges are highest at spine bases and then they gradually lower until they climb again on the next spine base. Generally, the shape of spine bases with radiating ridges strongly resembles the platelike supporting roots of some tropical threes.
Stem and branches. The stem grows more or less perpendicularly to the basal unit, is multilayered, branched and tubular with rounded central canal (Fig. 7A, B). Branches are also tubular, but in contrast to Sinopathes they are thin-walled, with low rate of increase in thickness with growth, not thickened (Fig. 7F, O, P, R). The external surface of branches is strongly sculptured by spines and radiating ridges identically as on the basal unit, although the ridges on branches seem even stronger and higher, platelike (e.g., Fig. 7B, C, O, R). The ridges vary considerably in thickness from 10 to $50 \mu \mathrm{m}$. They frequently form an anastomosing net of lamellae which markedly enlarge the total diameter of branches (Fig. 7C, R). Some ridges may be reinforced by slight thickening of their top edge (Fig. 7K, N). Occasionally, branches reveal very extensive and thickened net of ridges thus giving an apparent massiveness to the branches as a whole (Fig. 7D-H).

Spines. Although a majority of spines in the present material are broken off, a few complete ones show that they are slender, acicular, generally straight to slightly distorted, with narrowly conical base and smooth surface. The spines vary considerably in size and shape usually attaining $160-230 \mu \mathrm{m}$ in length, but the longest reach $500 \mu \mathrm{m}$. They are $60-80 \mu \mathrm{m}$ at the base, $25-60$ in the midlength, and 15-20 at the apex. The latter has a gently rounded top (Fig. 7H, I). The arrangement of spines is irregular. They 


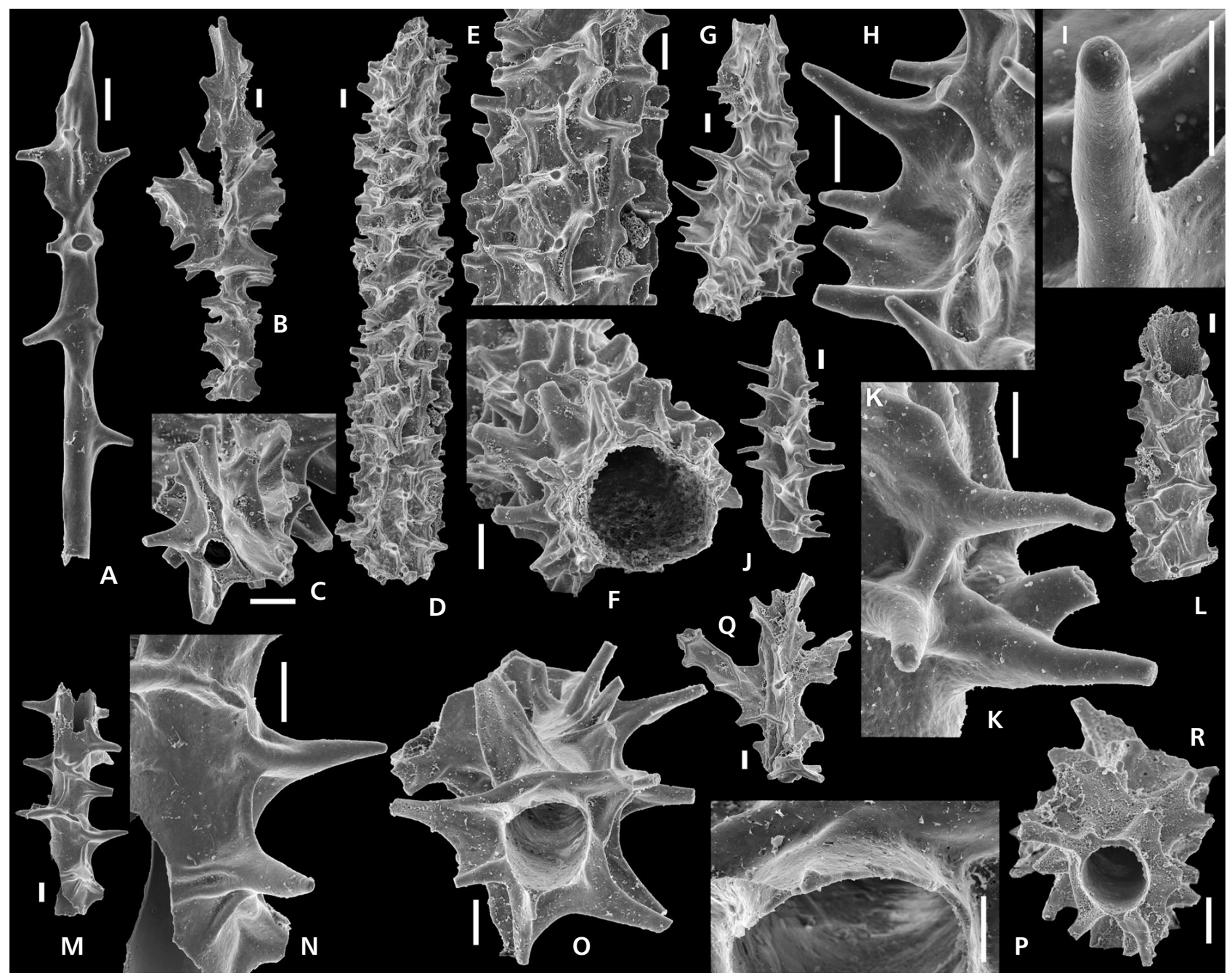

Figure 7. Morphology of lateral branches and spines in Sterictopathes radicatus gen. et sp. nov. from the Lower Ordovician Fenxiang Formation of Hubei Province, China. • A - small-sized, distal part of branch; ZPAL H. 27/21-28. • B, C - fragment of ramifying lateral branch in general and oblique views showing small central lumen and net of strong plate-like superficial ridges; ZPAL H. 27/28-18. • D-F - thick branch in general, enlarged and oblique views; note thin-walled central lumen; ZPAL H. 27/26-27. • G-I - fragment of a branch with well preserved surface morphology in general and enlarged views; note a well-preserved spine in I; ZPAL H. 27/30-6. $•$ J, K, M, N - two specimens in general and enlarged views showing well-preserved exterior; ZPAL H. 27/31-15 (JK), ZPAL H. 27/28-27 (MN). $\bullet$ - fragment of a branch; ZPAL H. 27/5-18. $\bullet$ O, P - transverse fracture of a branch in general and enlarged views showing extensive plate-like surface ridges, spines and thin-walled central lumen; ZPAL H. 27/31-13. $\bullet$ Q - branch with ramifications and strongly developed plate-like surface ridges; ZPAL H. 27/30-22. $\bullet$ R - transverse fracture showing central lumen, spines and plate-like surface ridges; ZPAL H. 27/27-29. Samples: Huanghua HB5 (J, K, O, P), Huanghua HB10 (B, C), Huanghua HB18 (A, M, N), Tianjialing T4 (Q), Tianjialing T6 (R), Tianjialing T13 (D-F, L). Scale bars $100 \mu \mathrm{m}$ (A-H, J, L-O, Q, R) and $50 \mu \mathrm{m}$ (I, K, P).

are buttressed basally by more or less radially disposed, strong, frequently plate-like ridges.

Remarks. - It is astonishing that the vast majority of specimens in the studied material have broken off spines with blunt and worn verges. Apparently this is a result of transport of the antipatharian remnants from shallower, reef related settings to deeper, depositional parts of a basin. Well preserved are surfaces of coralla on concave areas protected against abrasion by projecting spines and ridges. They may show a very well preserved network of pits (Fig. 6F) which probably represent imprints of the secretory epithelial cells (see Baliński et al. 2012, fig. 6). The imprints are generally of uniform size $6-9 \mu \mathrm{m}$ in diameter.

Sterictopathes radicatus gen. et sp. nov. is readily distinguished from the co-occurring antipatharian Sinopathes reptans by the presence of radiating ridges buttressing spines and by smooth, non-sculptured spines. In contrast to $S$. reptans, the branches in $S$. radicatus are less massive and thin-walled, but their mechanical strength is provided by a network of lamella-like ridges covering the 


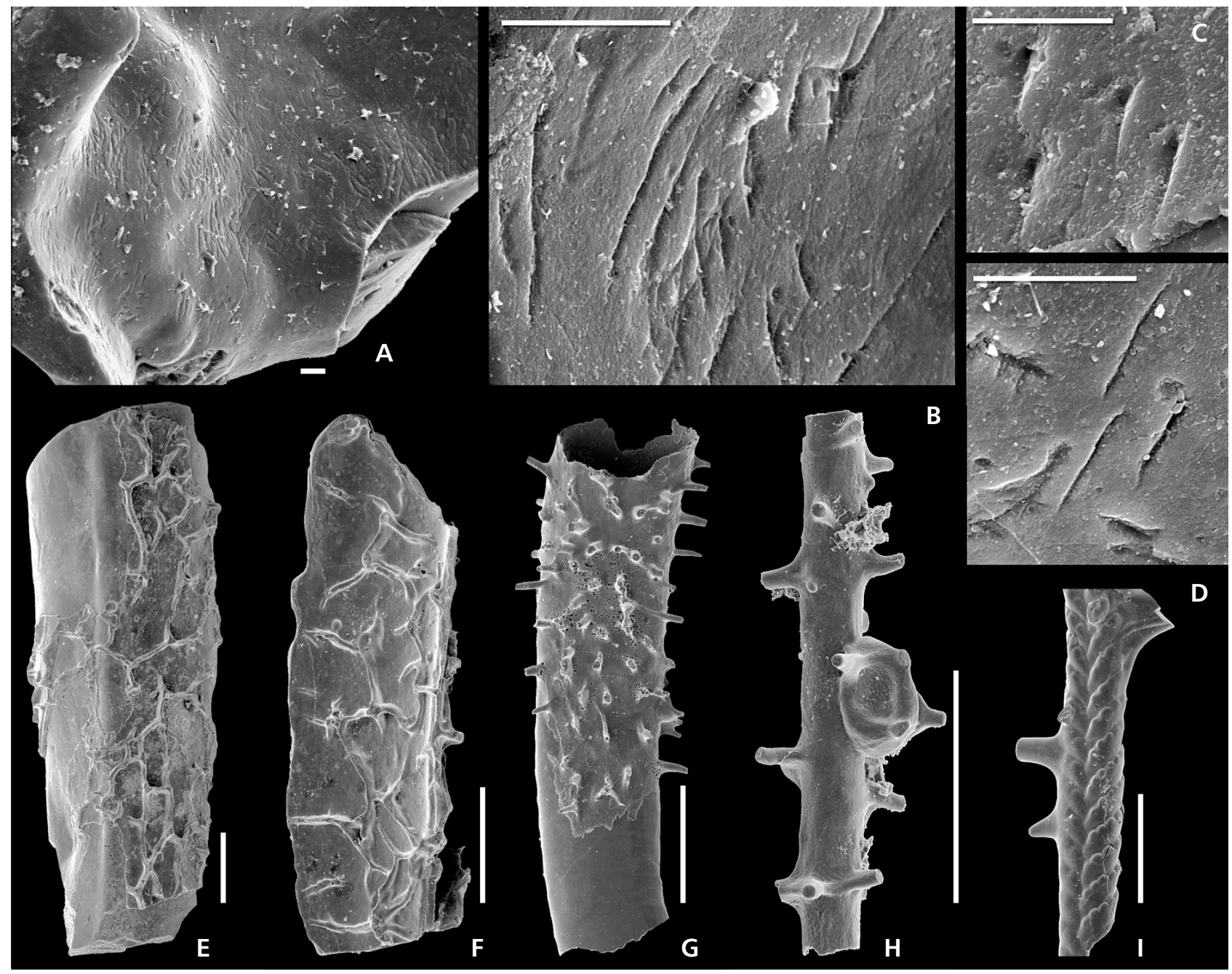

Figure 8. Evidences of biotic interaction in the Early Ordovician black corals from the Fenxiang Formation. $\bullet$ A-D - scratched surface of a corallum of Sinopathes sp., probably as a result of predator's attack; general view and three enlargements; ZPAL H. 27/7-13. • E-G - fragmentary specimens of Sphenotallus overgrown by Sterictopathes radicatus gen. et sp. nov.; ZPAL Sz. 2/2 (E), ZPAL H. 27/28-2 (F), ZPAL H. 27/28-38 (G). • H - probable graptolite prosicula attached to a branch of Sterictopathes radicatus gen. et sp. nov. and subsequently bioimmured; ZPAL H. 27/28-32. $\bullet$ I - bioimmured branch of possible pterobranch hemichordate Crinisdendrum sinicum Dzik, Baliński \& Sun, 2016 by Sinopathes sp.; ZPAL H. 27/27-3. Samples:

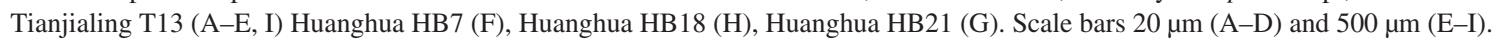

surface of branches. The radiating ridges are usually rather low on basal plates, but may be strong, high and plate-like on branches. It seems that basal plates, which firmly encrusted the substrate required less reinforcements than free thin-walled branches. The difference in structure of the skeleton between Sinopathes and Sterictopathes spectacularly shows different attempts to solve the problem of mechanical support for branched colonies of these black corals.

Occurrence. - The Fenxiang Formation; Tianjialing: beds T4, T5, T8, T13, T22; Huanghua: beds HB5, HB7, HB8, HB10, HB18; Jianjiafan: bed C(-1); a few poorly preserved specimens were found at the base of the Honghuayuan Formation at Gudongkou (sample 118A).

\section{Biotic interactions}

Recent antipatharians are known to host abundant associated fauna in their colonies, as crustaceans, polychaetes, mollusks, crinoids, ophiuroids and many others (e.g., Warner 1981, Molodtsova \& Budaeva 2007, Tazioli et al. 2007, Molodtsova \& Poltarukha 2008). Bo et al. (2012) described specific associations of black corals with stalked barnacles and parasitic zoanthids. The biotic interactions are much more difficult to identify in the fossil material studied because they are limited to traces on the fossilized coralla. In presently investigated material we found rare evidences of bioimmuration of other organisms by black corals. Bioimmured organisms were colonies of the possible pterobranch hemichordate Crinisdendrum sinicum 
Dzik, Baliński \& Sun, 2016 (see Dzik et al. 2016) (Fig.8I). The studied early Ordovician Sinopathes and Sterictopathes were found most commonly to encrust massive colonies of bryozoans and phosphatic tubes of Sphenothallus (Figs 6E, 8E-G).

Of special interest are numerous scratches found on one of the specimens of Sinopathes reptans (Fig. 8A-D). The scratches are sharp, 7-35 $\mu \mathrm{m}$ long and about $1 \mu \mathrm{m}$ wide. Usually they are grouped in sub-parallel sets of 2-4, more or less evenly set apart; suggesting that the scratches are marks of very sharp tooth- or spine-like appendages. Perhaps these are traces of a parasite/predator feeding on the soft tissue of black coral. Several parasitic invertebrates as well as vertebrates are known to feed on the coenenchyme of present-day antipatharians by scraping it from the surface of the corallum. Such kinds of parasitic behavior have been observed, e.g., in ovulid gastropods, caprellid amphipods, chaetodontid fish and green turtles (Seminoff et al. 2006, Tazioli et al. 2007).

\section{Acknowledgments}

We are grateful to Marzia Bo (Dipartimento di Scienze del Mare, Università Politecnica delle Marche, Ancona, Italy) for her generous gift of comparative material of recent antipatharians. We are deeply indebted to referees Stefan Bengtson (Swedish Museum of Natural History, Stockholm, Sweden) and Carlton E. Brett (University of Cincinnati, Cincinnati, USA) for their valuable comments and linguistic correction of our manuscript. SEM pictures were taken at the Institute of Paleobiology, Polish Academy of Sciences in Warsaw. The research was supported by the National Science Centre, Poland (grant DEC-2012/07/B/NZ8/02701).

\section{References}

ADACHI, N., EzAKI, Y. \& LiU, J. 2011. Early Ordovician shift in reef construction from microbial to metazoan reefs. Palaios 26, 106-114. DOI 10.2110/palo.2010.p10-097r

Adachi, N., EzAKI, Y. \& LiU, J. 2012.The oldest bryozoan reefs: a unique Early Ordovician skeletal framework construction. Lethaia 45, 14-23. DOI 10.1111/j.1502-3931.2011.00268.x

AdAchi, N., Liu, J. \& EZAKI, Y. 2013. Early Ordovician reefs in South China (Chenjiahe section, Hubei Province): deciphering the early evolution of skeletal-dominated reefs. Facies 59, 451-466. DOI 10.1007/s10347-012-0308-2

Baliński, A. \& Sun, Y. 2013. Preservation of soft tissues in an Ordovician linguloid brachiopod from China. Acta Palaeontologica Polonica 58, 115-120.

BALIŃski, A. \& Sun, Y. 2015. Fenxiang biota: a new Early Ordovician shallow-water fauna with soft-part preservation from China. Science Bulletin 60, 812-818.

DOI 10.1007/s11434-015-0762-7
Baliński, A., Sun, Y. \& DziK, J. 2012. 470-Million-year-old black corals from China. Naturwissenschaften 99, 645-53. DOI 10.1007/s00114-012-0947-8

Baliński, A., Sun, Y. \& DziK, J. 2013. Traces of marine nematodes from 470 million years old Early Ordovician rocks in China. Nematology 15, 567-574.

DOI 10.1163/15685411-00002702

Baliński, A., Sun, Y. \& DziK, J. 2014. Probable advanced hydroid from the Early Ordovician of China. Paläontologische Zeitschrift 88, 1-10.

DOI 10.1007/s12542-013-0169-1

Bo, M., Lavorato, A., Di Camillo, C.G., Poliseno, A., Baquero, A., Bavestrello, G., Irei, Y. \& Reimer, J.D. 2012. Black coral assemblages from Machalilla National Park (Ecuador). Pacific Science 66, 63-81. DOI 10.2984/66.1.4.

Brugler, M.R. \& France, S.C. 2007. The complete mitochondrial genome of the black coral Chrysopathes formosa (Cnidaria : Anthozoa : Antipatharia) supports classification of antipatharians within the subclass Hexacorallia. Molecular Phylogenetics and Evolution 42, 776-788.

DOI 10.1016/j.ympev.2006.08.016

Brugler, M.R., Opresko, D.M. \& France, S.C. 2013. The evolutionary history of the order Antipatharia (Cnidaria: Anthozoa: Hexacorallia) as inferred from mitochondrial and nuclear DNA: implications for black coral taxonomy and systematics. Zoological Journal of the Linnean Society 169, 312-361. DOI 10.1111/zoj.12060

CARTwright, P. 2003. Developmental insights into the origin of complex colonial hydrozoans. Integrative and Comparative Biology 43, 82-86. DOI 10.1093/icb/43.1.82

Dzik, J., Baliński, A. \& Sun, Y. 2016. An Early Ordovician clonal organism from China with a zig-zagged suture on branches. Bulletin of Geosciences 91, 319-329. DOI 10.315/bull.geosci.1575

ECHEVERRÍA, C.A. 2002. Black corals (Cnidaria: Anthozoa: Antipatharia): first records and a new species from the Brazilian coast. Revista de Biología Tropical 50, 1067-1077.

France, S.C., Brugler, M. \& Opresko, D. 2007. Order Antipatharia, 136-138. In Daly, M., Brugler, M.R., CARTwright, P., Collins, A.G., Dawson, M.N., Fautin, D.G., France, S.C., McFadden, C.S., Opresko, D.M., Rodriguez, E., Roman, S.L. \& Stake, J.L. (eds) The phylum Cnidaria: A review of phylogenetic patterns and diversity 300 years after Linnaeus. Zootaxa 1668.

Grange, K.R. 1988. Redescription of Antipathes aperta, Totton, (Coelenterata: Antipatharia), an ecological dominant in the southern fiords of New Zealand. New Zealand Journal of Zoology 15, 55-61. DOI 10.1080/03014223.1988.10422609

GuptA, N.S. \& BRIGGS, D.E.G. 2011. Chapter 5. Taphonomy of animal organic skeletons through time, 199-221. In Allison, P.A. \& BotTJER, D.J. (eds) Taphonomy: Process and bias through time. Topics in Geobiology 32.

Lapian, H.F.N., Barucca, M., Bavestrello, G., Biscotti, M.A., Bo, M., Canapa, A., Tazioli, S. \& Olmo, E. 2007. A systematic study of some Black Corals species (Antipatharia, Hexacorallia) based on rDNA internal transcribed spacers sequences. Marine Biology 151, 785-792.

DOI 10.1007/s00227-006-0525-8

Lehnert, O., Miller, J.F. \& Cochrane, K. 1999. Palaeobotryllus 
and friends: Cambro-Ordovician record of probable ascidian tunicates. Acta Universitatis Carolinae, Geologica 43, 447-450.

Molodtsova, T. \& Budaeva, N. 2007. Modifications of corallum morphology in black corals as an effect of associated fauna. Bulletin of Marine Science 81, 469-480.

Molodtsova, T.N. \& Pasternak, F.A. 2005. Redescription of Parantipathes euantha (Pasternak, 1958) (Anthozoa: Antipatharia) from Kurile-Kamchatka Trench. Invertebrate Zoology 2, 169-179.

Molodtsova, T. \& Poltarukha, O. 2008. Cuticular spines of Oxynaspis spp. (Pedunculata: Cirripedia): An inheritance from antipatharian host, 215. In NeIL, H. \& Tracey, D. (eds) Deepsea Coral Symposium 2008, $4^{\text {th }}$ ISDSC, Programme and Abstract Book. NIWA, Wellington, New Zealand.

MüLLER, K.J. 1977. Palaeobotryllus from the Upper Cambrian of Nevada - a probable ascidian. Lethaia 10, 107-118. DOI 10.1111/j.1502-3931.1977.tb00600.x

Opresko, D.M. 2001. Revision of the Antipatharia (Cnidaria: Anthozoa). Part I. Establishment of a new family, Myriopathidae. Zoologische Mededelingen Leiden 75, 343-370.

OpRESKo, D.M. 2002. Revision of the Antipatharia (Cnidaria: Anthozoa). Part II. Schizopathidae. Zoologische Mededelingen Leiden 76, 411-442.

Opresko, D.M. 2004. Revision of the Antipatharia (Cnidaria: Anthozoa). Part IV. Establishment of a new family, Aphanipathidae. Zoollogische Mededelingen Leiden 78, 209-240.

OPRESKO, D.M. 2006. Revision of the Antipatharia (Cnidaria: Anthozoa). Part V. Establishment of a new family, Stylopathidae. Zoollogische Mededelingen Leiden 80, 109-138.

Opresko, D.M., Wagner, D., Montgomery, A.D. \& Brugler, M.R. 2012. Discovery of Aphanipathes verticillata (Cnidaria: Anthozoa: Antipatharia) in the Hawaiian Islands. Zootaxa 3348, 24-39. DOI 10.11646/\%25x

Pasternak, F.A. 1977. Antipatharia. Scientific results of the Danish Deep-Sea Expedition round the world 1950-1952, 157-164. In WolfF, T. (ed.) Galathea Report, Vol. 14. Scandinavian Science Press, Copenhagen.

Roark, E.B., Guilderson, T.P., Dunbar, R.B., Fallon, S.J. \& Mucciarone, D.A. 2009. Extreme longevity in proteinaceous deep-sea corals. Proceedings of the National Academy of Sciences 106, 5204-5208. DOI 10.1073/pnas.0810875106
Rodríguez, E., Barbeitos, M.S., Brugler, M.R., Crowley, L.M., Grajales, A., Gusmão, L., Häussermann, V., Reft, A. \& DALY, M. 2014. Hidden among sea anemones: the first comprehensive phylogenetic reconstruction of the order Actiniaria (Cnidaria, Anthozoa, Hexacorallia) reveals a novel group of hexacorals. PLoS One 9, e96998.

DOI 10.1371/journal.pone.0096998

SEminOFF, J.A., Jones, T.T. \& MARshall, G.J. 2006. Underwater behaviour of green turtles monitored with video-time-depth recorders: what's missing from dive profiles? Marine Ecology Progress Series 322, 269-280. DOI 10.3354/meps322269

Stolarski, J., Kitahara, M.V., Miller, D.J., Cairns, S.D., Mazur, M. \& Meibom, A. 2011. The ancient evolutionary origins of Scleractinia revealed by azooxanthellate corals. BMC Evolutionary Biology 11, 316.

DOI 10.1186/1471-2148-11-316

Tazioli, S., Bo, M., Boyer, M., Rotinsulu, H. \& Bavestrello, G. 2007. Ecology of some common antipatharians from the Marine Park of Bunaken (North Sulawesi, Indonesia). Zoological Studies 46, 227-241.

Wagner, D., Luck, D.J. \& Toonen, R.J. 2012. The biology and ecology of black corals (Cnidaria: Anthozoa: Hexacorallia: Antipatharia). Advances in Marine Biology 63, 67-132. DOI 10.1016/B978-0-12-394282-1.00002-8

WAGNER, D. \& OpResko, D.M. 2015. Description of a new species of Leiopathes (Antipatharia: Leiopathidae) from the Hawaiian Islands. Zootaxa 3974, 277-289.

DOI 10.11646/zootaxa.3974.2.11

WARNER, G.F. 1981. Species descriptions and ecological observations of black corals (Antipatharia) from Trinidad. Bulletin of Marine Science 31, 147-163.

Wells, J.W. \& Hill, D. 1956. Ceriantipatharia, 165-166. In Moore, R.C. (ed.) Treatise on Invertebrate Paleontology. Part F. Coelenterata. Geological Society of America \& University of Kansas Press, Lawrence, Kansas.

Williams, B., Risk, M.J., Ross, S.W. \& Sulak, K.J. 2006. Deep-water antipatharians: proxies of environmental change. Geology 34, 773-776. DOI 10.1130/G22685.1

Wu, R., Stouge, S., Li, Z. \& WAng, Z. 2010. Lower and Middle Ordovician conodont diversity of the Yichang Region, Hubei Province, Central China. Bulletin of Geosciences 85, 631-644. DOI 10.3140/bull.geosci.1188

Zhan, R. \& Jin, J. 2007. Ordovician-Early Silurian (Llandovery) stratigraphy and palaeontology of the Upper Yangtze Platform, South China. 169 pp. Science Press, Beijing. 